\title{
Research-Based Learning in Initial Teacher Education in Catalonia
}

INGRID AGUD ${ }^{\star 1}$ AND GEORgETA ION ${ }^{2}$

$\approx$ The teaching profession is undergoing significant changes, some of which are imposed by the new paradigm of education. This new context marks the shift from the teachers' position as 'knowledge users' towards the more complex position of 'knowledge creators'. In this new professional culture adapted to a changing society, teaching as a profession is understood as undergoing a continuous transformation and innovation process, while the professionals in the educational field appear to be research users and research promoters able to think thoroughly about their own professional needs and the new topics arising in their field. There is, therefore, a shift from a passive to an active position, enabling educators to become aware of how complex their field is and to understand that it cannot be acknowledged and managed from outside the social, cultural, historical, philosophical, and psychological contexts shaping it. Taking into consideration the characteristics of the new professional culture, this paper is focused on the development of research skills as one of the teachers' core skills. The study is framed at the Universitat Autonoma de Barcelona, where the Student Perception Research Integration Questionnaire (SPRIQ) of Visser-Wijnveen et al. (2015) was applied to measure students' perception of research integration in university courses $(n=113)$. Additionally, analysis of the documents on the syllabus of each course of the BA in Primary Education programme was applied to review the research component of initial teacher education curricula. Findings from students' responses show that they are more consumers than producers of research. We emphasise the importance of student teachers being able to both consume as well as produce research in order to develop professionally.

Keywords: research-based learning, research integration in curriculum, teacher education

$1 \quad{ }^{\star}$ Corresponsing Author. Department of Systematic and Social Pedagogy, Faculty of Education Sciences, Universitat Autònoma de Barcelona, Spain; ingrid.agud@uab.cat.

2 Department of Applied Pedagogy of the Universitat Autònoma de Barcelona, Spain. 


\section{Na raziskavah temelječe učenje $\mathrm{v}$ začetnem izobraževanju učiteljev v Kataloniji}

INGRID Agud IN GEORgEta ION

$\propto$ Učiteljski poklic se spoprijema s pomembnimi spremembami, od katerih so nekatere posledica nove paradigme izobraževanja. $\mathrm{V}$ novem kontekstu gre za premik v vlogi učiteljev kot »uporabnikov znanja« h kompleksnejši vlogi »ustvarjalcev znanja«. V tej novi poklicni kulturi, ki se prilagaja spreminjajoči se družbi, se poučevanje kot poklic dojema kot proces nenehnega preoblikovanja in inovacij, strokovnjaki na področju izobraževanja pa kot uporabniki raziskav in spodbujevalci, ki so sposobni celovito razmišljati o svojih lastnih poklicnih potrebah in novih temah na tem področju. Gre za premik od pasivne k aktivni vlogi, ki omogoča delavcem v izobraževanju ozaveščenost o kompleksnosti tega področja in tem, da ga ni mogoče razumeti in upravljati zunaj socialnih, kulturnih, zgodovinskih, filozofskih in psiholoških kontekstov, ki ga oblikujejo. Ob upoštevanju značilnosti nove poklicne kulture se ta članek osredinja na razvoj raziskovalnih veščin kot ene temeljnih veščin učiteljev. Študija, ki je bila izvedena pod okriljem univerze Universitat Autònoma de Barcelona, je uporabila potrjen vprašalnik (Visser-Wijnveen et al., 2015) za merjenje mnenj študentov o vključitvi raziskav v univerzitetne programe $(n=113)$. Poleg tega so bili analizirani dokumenti učnih načrtov vsakega predmeta dodiplomskega študijskega programa za študente razrednega pouka $\mathrm{z}$ namenom pregleda raziskovalnih komponent $\mathrm{v}$ učnih načrtih začetnega izobraževanja učiteljev. Ugotovitve na podlagi odgovorov študentov kažejo, da so ti bolj uporabniki kot oblikovalci raziskav. Poudarjamo pomembnost sposobnosti študentov - bodočih učiteljev - za uporabo in oblikovanje raziskav za njihov poklicni razvoj.

Ključne besede: na raziskavah temelječe učenje, vključitev raziskav v kurikulum, izobraževanje učiteljev 


\section{Introduction}

The development of teacher research competence and research-based teacher education, as an approach and phenomenon of the $21^{\text {st }}$ century, have received increasing interest among policymakers, researchers of teacher education, and teachers in many countries of the world, based on the assumption that they are a means to improving teacher education.

Over the previous decade, European bodies have shown their commitment to the field of teacher education.

The Draft Conclusions of the Council and of the Representatives of the Governments of the Member States, meeting within the Council, on Improving the Quality of Teacher Education adopted in October 2007 (European Union, 2007), provides a useful reminder of the mission of teaching, stating:

teaching provides a service of considerable social relevance: teachers play a vital role in enabling people to identify and develop their talents and to fulfil their potential for personal growth and well-being, as well as helping them to acquire the complex range of knowledge, skills and key competences that they will need as citizens throughout their personal, social and professional lives. (p. 300/7)

Teachers should possess a set of key competences to carry out this mission; in this framework, the European Union education ministers also emphasised the need for today's teachers to 'develop new knowledge and be innovative through engagement in reflective practice and research (European Union, 2007).

In 2015, the European Commission published a guide on policies to improve initial teacher education. Two of the suggested policy actions are related to teacher research competence. The Commission (2015) recommends: To achieve a creative and reflective teaching workforce, policies and actions should encourage student teachers and teachers to use and engage in new research in their learning and practice. While Initial Teacher Education (ITE) lays the foundations for this, policy actions should foster innovative cultures in schools and ensure they have links with universities and other organisations that support research-informed development of teaching practices.

Action research is suggested, by the European Commission in this guide, as a mode of finding a valid solution to a challenge in classroom practice (European Commission, 2015).

Several researchers have contributed to developing the theory of research in general and teacher research in particular. An impressive number of 
papers have been published on research-based education in recent years, to make it a core topic of the educational practices in many countries. Those holding top positions in the international rankings in terms of education quality are the same countries that have contributed the most to developing this paradigm (e.g., Finland and Norway).

Hopkins (2008) presents a rationale for teacher research, focused on three themes that justify and make imperative the concept of classroom research by teachers. He identifies:

The first is the link between classroom research by teachers and the establishing and refining of professional judgement. The second is making the focus of classroom research the curriculum and teaching learning. The third is the inappropriateness of the traditional research paradigm for helping teachers to improve their teaching. (2008, p. 41)

In this line, Kincheloe (2012) considers that teachers have to deal with new challenges in current society, which highlights the role of the teacher as knowledge constructor and reflexive practitioner. The author summarises the following changes teachers have to deal with:

- $\quad$ Constructing a system of meaning.

- Understanding dominant research methods and their effects.

- Selecting what to study.

- $\quad$ Acquiring a variety of research strategies.

- Making sense of the information collected.

- Gaining awareness of the tacit theories and assumptions which guide practice.

- Viewing teaching as an emancipator praxis-based act.

Taber (2007), explaining the importance of research skills during initial teacher education, summarises:

[...] in the 21st century context of being a teacher, there is an expectation of engaging with, and to some extent in, educational research; in the 21st century context of becoming a teacher, there is an expectation of being prepared to engage with, and to some extent in, educational research; in the 21st century context of becoming a teacher through a postgraduate route, there is an expectation of engaging with educational research at a high academic level. (2007, p. 10) 
Considering the importance of student teachers research skills, ETUCE (2009) states that student teachers must acquire theoretical knowledge and skills in research methodologies to organise, implement and analyse research and development work usually within their own classroom or school and elsewhere.

\section{Changing role of teachers from knowledge users to knowledge creators}

The teaching profession is undergoing important significant changes, in particular, within the new paradigm of education. This new context marks the shift from the teachers' position as 'knowledge users' towards the more complex position of 'knowledge creators'. In this new professional culture adapted to a changing society, teaching as a profession is understood as undergoing a continuous transformation and innovation process, while the professionals in the educational field appear to be research users and research promoters able to think thoroughly about their own professional needs and the new topics arising in their field.

There is, therefore, a shift from a passive to an active position enabling educators to become aware of how complex their field is and to understand that this field cannot be acknowledged and managed from outside the social, cultural, historical, philosophical, and psychological context shaping it. Teachers thus become aware not only of the students' immediate needs and of the facts occurring during their classes but also of their training and professional needs. According to authors such as Kraft (2001) and Beretter (2002), the teachers become the researchers of their professional practice.

When teachers accept their position as researchers, they take a critical attitude towards the real problems of the educational context in which they carry out their activities, and thus they become active players in the teaching innovation process.

When the teaching activity is based on inquiry, the entire educational process helping to train future experts in the education field is designed around knowledge, producing it, and the skill for using it effectively.

The starting point of this process is obviously the initial training system for education professionals. In a research-based education model, all training courses are in keeping with the investigation and are related to solving real problems issued from the professional field. Krokfors et al. (2011) consider training to be enabling the teachers to be autonomous and reflexive professionals, able to act as researchers and characterised by a high level of self-reflection. The aim is not merely producing researchers, but also endowing students and future 
professionals with sufficient competences and knowledge to empower them to apply what they have learnt, to observe the students, to analyse what they think, and to find solutions for the needs identified (Kansanen, 2007; Krokfors, 2007; Toom et al., 2010; Westbury et al., 2005, among others).

Several authors have been studying the teaching-research nexus; Healey (2005) provides a diagram that illustrates curriculum design and researchteaching nexus. He has presented four different approaches to the teaching-research nexus using two axes. One classifies approaches to linking teaching and research according to the extent to which they are teacher-focused in which students are seen as the audience or student-focused and treat students as participants. The second axis classifies the approach as emphasising research content or research processes and problems.

\section{STUDENT-FOCUSED}

\section{STUDENTS AS PARTICIPANTS}

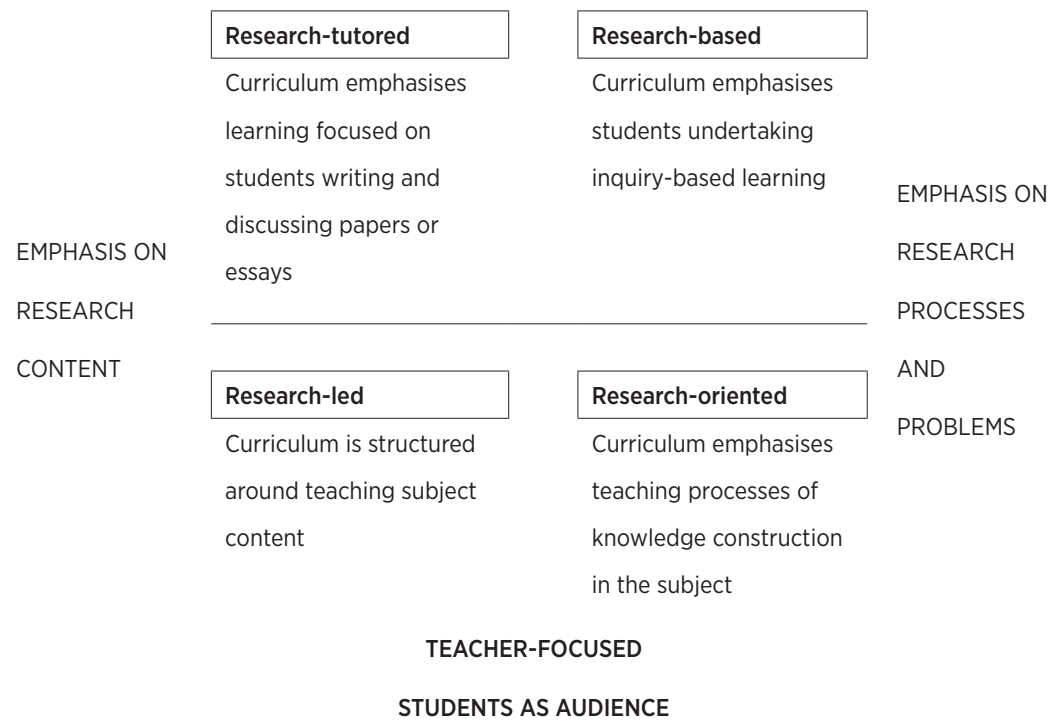

Figure 1. Healey's Diagram. Adapted from Healey, 2005.

Krokfors et al. (2011) think that a research-based training process starts with teachers needing in-depth knowledge of the latest and the most relevant research results in their teaching field. Simultaneously, they need to be familiar with the latest evolutions in terms of teaching and learning methods and techniques. Interdisciplinary research and teaching knowledge are the bases necessary to develop methods that can be adapted to various students' profiles. 
The second important element, according to the research-based paradigm, is that the teachers' training can be considered an investigation and research topic in itself. This research work must provide the necessary knowledge of the quality and effectiveness of various educational systems and different teaching approaches. Specifically, any approach of research-based education aims to make the teachers-to-be develop an attitude oriented towards curiosity and research throughout their activity. This means that they learn how to approach their profession in an open and analytical manner and how to build their conclusions on observation and experimentation while carrying out their work in a systematic and complex manner (Niemi \& Jakku-Sihvonen, 2006).

The various studies showed that students, both undergraduate and postgraduate, perceived benefits as well as challenges when links between research and teaching were emphasised. Perceived benefits included increased motivation and interest in the subject because of the teacher's enthusiasm and greater credibility (Jenkins et al., 1998; Robertson \& Blackler 2006).

Jenkins and Healy (2009) argue that too much of higher education relates to students as an audience and that students would benefit from spending more time as participants in research processes. It is proposed that in preservice teacher education, the vast majority of research related activity that students undertake should be related to research-led learning. Students are expected to relate their assignments, essays and examination papers to prevailing literature and academics see this as a way to promote scholarship in their learning experience. This approach sees undergraduate students as passive receivers of knowledge using the same transmissive pedagogy that most teachereducators criticise (using arguments such as those presented by Carroll, 1998).

A research-based approach in teacher education is arguably as important as in any scientific discipline, if not more. Unlike many of the sciences in which knowledge and principles are relatively stable from context to context, teaching is a decidedly complex discipline that is highly context dependent. This means that while teachers can draw upon some theoretical frameworks to inform their practice, they may need to extrapolate, reinterpret, or redefine approaches depending on the specific circumstances of their students, classroom environment, school and community. That is to say, research-based approaches to teaching are required in order to be an effective teacher (Buckley, 2011).

\section{Method}

This paper presents the preliminary inquiry of a research project which aims to investigate the development of research competence in initial teacher 
education and to present ways how to reshape teacher education using a research-based approach.

This research has three main aims: 1) to review the research component of initial teacher education curricula; 2 ) to gain a greater understanding of how student teachers perceive and experience the research skills development; 3) to identify the quality, motivation, and participation on research during the bachelor's degree.

\section{Setting}

The study was implemented at the Faculty of Education Sciences of the Universitat Autònoma de Barcelona (UAB), specifically at the bachelor's degree in Primary Teacher Education, which is a four-year university programme that offers the basic training needed to teach to 6- to 12-year-olds within the context of Catalonia's compulsory education system. This faculty is one of the most innovative higher education institutions in Catalonia for teacher education as well as being a pioneer in offering courses in English, Spanish, and Catalan, applying methodology of the Content and Language Integrated Learning approach ${ }^{3}$ (CLIL) (also called 'ICLHE', meaning Integrating Content and Language in Higher Education) (Wilkinson, 2015) in the Spanish context. As a pioneer regarding the internationalisation of faculties, the faculty would also like to pioneer training teachers with research skills to create knowledge from their daily practice.

\section{Sample}

For this preliminary analysis, the students of Primary Teacher Education Degree were studied. In total, 240 students were enrolled in the degree programme, and the sample consisted of 113 students who consented to participate in the research ( $89.4 \%$ female; $9,7 \%$ male; $0.9 \%$ agender). The sample size calculation considering a $95 \%$ confidence level for finite populations ( $\mathrm{p}$ and $\mathrm{q}=0.5$ ) indicated that the margin of error was \pm 6.72 . Table 1 below shows the sample description regarding the level of the students.

3 Approach for learning academic contents by using a third language (Marsh, 1994). 
Table 1

Sample description per academic year

\begin{tabular}{lcc}
\hline Year & Frequencies & Percentage \\
\hline $1^{\text {st }}$ & 38 & 33.6 \\
$2^{\text {nd }}$ & 24 & 21.2 \\
$3^{\text {rd }}$ & 17 & 15.1 \\
$4^{\text {th }}$ & 34 & 30.1 \\
\hline Total & 113 & 100.0 \\
\hline
\end{tabular}

Regarding the first objective (to review the research component of initial teacher education curricula), we applied document analysis to the syllabus of each course of the BA in Primary Education. Table 2 shows all courses for each year, listed regarding whether they are compulsory or optional subjects.

Table 2

Study plan structure for Primary Teacher Education at UAB

\begin{tabular}{ll}
\hline \multicolumn{2}{c}{ Compulsory Training } \\
\hline 1 $^{\text {st }}$ year & $2^{\text {nd }}$ year \\
- Education and Educational Contexts & - Learning and Development I \\
- Society, Science and Culture & - Teaching Methods and Curriculum Develop- \\
- Educational Communication and Interaction I & ment \\
and II & - Social Context and School Management \\
- Contemporary Theories and Practices in & - Physical Education in Primary Education \\
Education & - Learning Mathematics and the Curriculum \\
- Languages and Contexts I and II & - Languages and Curricula \\
& - Teaching and Learning about the Natural, \\
& Social and Cultural Environment \\
& - Musical and Visual Education \\
\hline $3^{\text {rd }}$ year & $4^{\text {th }}$ year \\
- Learning and Development II & Practicum IV and V \\
- Differences and Inclusion & Bachelor's Degree Final Research Project \\
- Languages and Learning & \\
- Management and Innovation in the Math- & \\
- Musical and Visual Education and Learning & \\
- Planning, Research and Innovation & \\
- Teaching Experimental Sciences & \\
- Physical Education and its Teaching I & \\
- Centre's Linguistic Project and Multilingual- & \\
\hline
\end{tabular}




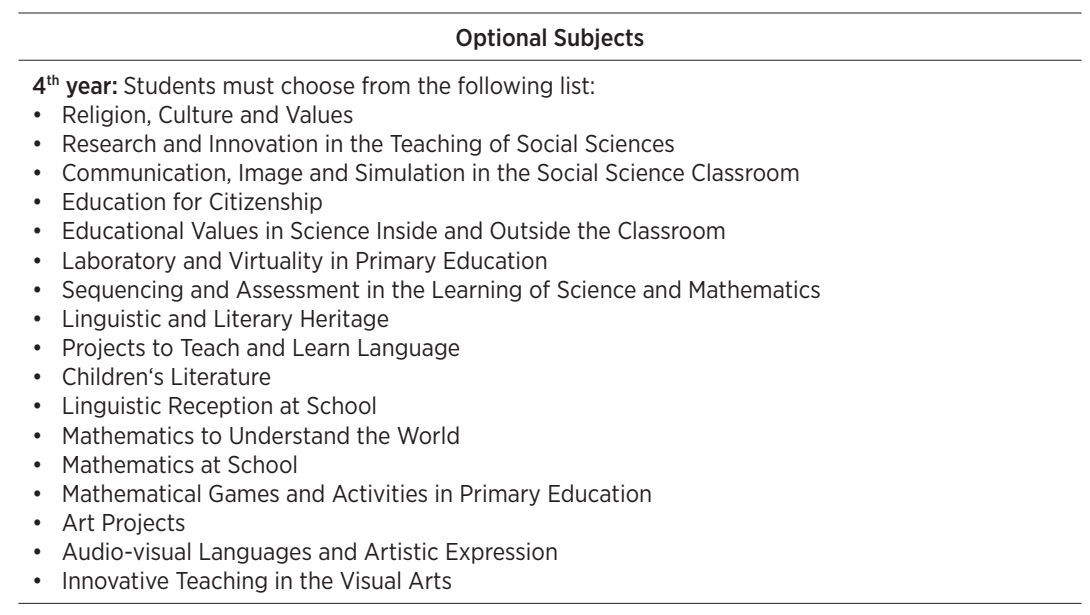

\section{Instrument and techniques}

The questionnaire constructed and validated by Visser-Wijnveen, Van der Rijstn, and Van Driel (2015) was applied to measure student perception of research integration in university courses named Student Perception of Research Integration Questionnaire (SPRIQ).

This instrument is a tool of 40 items scored on a five-point Likert scale. The questionnaire consists of three constructs (Visser-Wijnveen et al., 2015, p. 6): 'research integration', 'quality of the course', and 'beliefs about research integration'. Among the 40 items, 36 were scored on a frequency scale, ranging from very rarely to very frequently, while the four questions of the beliefs scale were scored on an agreement scale, ranging from strongly disagree to strongly agree.

The scale applied to the sample shows a high level of reliability with a Cronbach Alpha of .963; being above .80, it proves good internal consistency of the scale.

For the purposes of this research, document analysis of primary education study programmes was carried out, searching for the research component on the syllabus of the different subjects to analyse how research is integrated into the educational curriculum of teacher education.

\section{Procedure}

The questionnaire was completed in class in May 2016. Once the data were gathered, univariate and multivariate statistical analyses were performed using IBM Statistical Package for the Social Sciences (SPSS v.20). 
Syllabi of the courses were analysed in January 2017 and up to this point they have not been yet modified in the current year.

\section{Results}

\section{Findings from curricula documents review.}

As it described in the degree's presentation note, the Bachelor's Degree in Primary Education aims to provide basic training needed to work as a teacher of the 6- to 12-year age group in compulsory education. The degree is based on the teaching methods of Rosa Sensat, known throughout the country for her tasks as an educator and teacher. The bachelor's degree aims to train professionals prepared to teach within the context of the Catalan school system.

To complete the training, students must achieve a total of 240 ECTS, the distribution of which is shown in Table 3. If the students want to have a European recognition according to the Bologna criteria, they also should do a minimum of 30 ECTS (five courses) related to different specialisation programmes. The specific programmes are: Physic Education; Foreign Languages: English; Foreign Languages: French; Special Educational Needs; Music Education; Language and Literature; Mathematics; Social Sciences; Experimental Sciences; Visual Education and Arts; Scientific Education and Mathematics for Digital Tools; Scientific Education and Social Studies with Digital Tools and Multimedia Resources and Language and Social Studies.

Table 3

European Credits (ECTS) for the Bachelor of Primary Education at the UAB

\begin{tabular}{lcccc}
\hline Year & Basic Training & Compulsory & Optional & Final Research Project \\
\hline 1 & 30 & 30 & & \\
2 & 18 & 42 & & \\
3 & 12 & 48 & & \\
4 & & 24 & 30 & 6 \\
\hline Total & 60 & 144 & 30 & 6 \\
\hline
\end{tabular}

Note. Credit (ECTS) point corresponds with 25 hours of academic load.

After reviewing the syllabus of the courses, we were confounded by the fact that the research component in the curriculum of the programme for a BA in Primary Education is only specified as such in the subject Planning, Research 
and Innovation (6 credits) offered in the third year. We also could find a research component in the Bachelor's Degree Research Project (6 credits) planned for the fourth year of studies.

In relation to the curriculum at the $\mathrm{UAB}$, the only skills related to research are formulated as follows:

- Develop learning and academic skills and strategies to acquire a sufficient level of autonomy in one's studies and, at the same time, understand the importance of refreshing one's training on a permanent basis. (Basic)

- $\quad$ Promote critical reading and comment regarding the different scientific domains contained in the school curriculum. (Specific)

- Manage the information related to the professional environment for making decisions and producing reports. Critically analyse the work done. (Transversal)

- $\quad$ Recognise and evaluate the social reality and the interrelation with implied factors in anticipation of any action. (Transversal)

However, we are aware that the introduction of the research component in the Teacher's Training also relies upon the methodologies and learning strategies applied by the professors to enhance research skills. These methodologies are not necessarily specified in the syllabus. Therefore, we recognise the need to develop the study further and add an inquiry to professors in order to be able to identify further research components in their teaching methods.

\section{Student perceptions of research-based approaches.}

We first present a descriptive analysis of Items of the Student Perception of Research Integration Questionnaire (SPRIQ) (Visser-Wijnveen et al., 2015) such are means and standard deviation, as seen in table 4.

Table 4

Means and Standard deviation for the Items of the Student Perception of Research Integration Questionnaire (SPRIQ)

\begin{tabular}{lcc}
\hline \multirow{2}{*}{ ITEM } & \multicolumn{2}{c}{ UAB } \\
\cline { 2 - 3 } & M $^{\text {a }}$ & SD \\
\hline 1. During my studies, I assimilated knowledge about research findings & 3.19 & .822 \\
2. During my studies I learned to pay attention to the way research is carried \\
$\quad \begin{array}{l}\text { out } \\
\text { 3. During my studies, I developed an academic disposition }\end{array}$ & 3.12 & .933 \\
$\begin{array}{l}\text { 4. During my studies, there were opportunities to talk with researchers about } \\
\text { scientific research }\end{array}$ & 3.30 & .885 \\
\hline
\end{tabular}




\begin{tabular}{|c|c|c|}
\hline \multirow{2}{*}{ ITEM } & \multicolumn{2}{|c|}{ UAB } \\
\hline & $\mathrm{M}^{\mathrm{a}}$ & SD \\
\hline 5. During my studies, attention was paid to recent developments in the field & 2.89 & 1.097 \\
\hline $\begin{array}{l}\text { 6. During my studies, the scientific research process was an essential part of } \\
\text { the curriculum }\end{array}$ & 2.62 & 1.020 \\
\hline 7. During my studies, I was inspired to learn more about this discipline & 3.08 & 1.045 \\
\hline $\begin{array}{l}\text { 8. During my studies, my understanding of the most important concepts in } \\
\text { the domain has increased }\end{array}$ & 3.48 & .917 \\
\hline 9. During my studies, attention was paid to research methodology & 2.96 & .944 \\
\hline 10. During my studies, I felt part of the university's academic community & 2.89 & 1.072 \\
\hline $\begin{array}{l}\text { 11. During my studies, I became familiar with the research carried out by my } \\
\text { teachers }\end{array}$ & 2.53 & 1.010 \\
\hline $\begin{array}{l}\text { 12. During my studies, my teachers encouraged me not to be satisfied with an } \\
\text { explanation too quickly }\end{array}$ & 2.95 & 1.109 \\
\hline $\begin{array}{l}\text { 13. During my studies, we searched for answers to unanswered research } \\
\text { questions together with the teachers }\end{array}$ & 2.41 & 1.107 \\
\hline 14. During my studies, I became enthusiastic about my scientific domain & 2.61 & 1.081 \\
\hline 15. During my studies, my contribution to the research was valued & 2.48 & 1.158 \\
\hline 16. During my studies, I came in contact with my teachers' research & 2.32 & 1.029 \\
\hline 17. During my studies my participation in the research was important & 2.35 & 1.140 \\
\hline $\begin{array}{l}\text { 18. During my studies, I got the opportunity to hear about current scientific } \\
\text { research }\end{array}$ & 2.78 & 1.041 \\
\hline 19. During my studies, I became familiar with the results of scientific research & 2.77 & 1.009 \\
\hline 20. During my studies, I was stimulated to critically assess literature & 2.95 & 1.109 \\
\hline 21. During my studies, I felt involved in the university's research culture & 2.32 & 1.029 \\
\hline $\begin{array}{l}\text { 22. During my studies, my awareness of the research issues that scientific } \\
\text { researchers are currently contributing to was increased }\end{array}$ & 2.70 & .981 \\
\hline $\begin{array}{l}\text { 23. During my studies, I learned what kind of studies have been carried out in } \\
\text { my field }\end{array}$ & 3.00 & 1.061 \\
\hline 24. During my studies, my interest in research in this area was increased & 3.08 & 1.062 \\
\hline 25. During my studies, I made a contribution to development in my field & 2.31 & 1.036 \\
\hline $\begin{array}{l}\text { 26. During my studies, I learned the ways in which research can be conducted } \\
\text { in this field }\end{array}$ & 2.96 & 1.026 \\
\hline $\begin{array}{l}\text { 27. During my studies, the teachers encouraged us to ask critical questions } \\
\text { about our work }\end{array}$ & 3.72 & 1.114 \\
\hline 28. During my studies as a student, I felt involved with the research & 2.69 & 1.036 \\
\hline $\begin{array}{l}\text { 29. During my studies, I had opportunities to socially interact with researchers } \\
\text { within the university }\end{array}$ & 2.10 & .916 \\
\hline 30. During my studies. links to current research practices were made & 2.66 & .997 \\
\hline 31. During my studies, I became involved in my teachers' research & 2.21 & 1.089 \\
\hline $\begin{array}{l}\text { 32. During my studies, my teachers encouraged personal interest and enthusi- } \\
\text { asm for research in this field }\end{array}$ & 2.92 & 1.151 \\
\hline $\begin{array}{l}\text { 33. During my studies, the teachers had sufficient time to support me in my } \\
\text { learning process }\end{array}$ & 2.71 & 1.058 \\
\hline
\end{tabular}




\begin{tabular}{|c|c|c|}
\hline \multirow{2}{*}{ ITEM } & \multicolumn{2}{|c|}{ UAB } \\
\hline & $M^{a}$ & SD \\
\hline 34. During my studies the teachers carried out their instruction adequately & 3.06 & .859 \\
\hline $\begin{array}{l}\text { 35. During my studies, my teachers were able to explain the subject matter } \\
\text { effectively }\end{array}$ & 3.15 & .858 \\
\hline $\begin{array}{l}\text { 36. During my studies, I developed an accurate picture of what was expected } \\
\text { of me }\end{array}$ & 3.04 & 1.109 \\
\hline 37. My learning is stimulated when education is grounded in research & 3.20 & 1.070 \\
\hline 38. It is important to me that my teachers conduct research & 3.54 & 1.134 \\
\hline 39. Education in which scientific research is central stimulates my learning & 3.18 & 1.071 \\
\hline 40. The research culture at the university stimulates my learning process & 2.96 & 1.093 \\
\hline
\end{tabular}

Note. ${ }^{\mathrm{a}}=$ On a response scale of 1-5.

First, it is noteworthy that at the UAB students think that During their studies. the teachers encouraged them to ask critical questions about their work, presenting this item the higher mean (3.72). According to Visser-Wijnveen et al (2015), this item refers to the academic disposition encouraged my research. Students also state that it is important to them that teachers conduct research $(\mathrm{M}=3.54)$, which relates with the beliefs about research integration in class. Finally, the following highest scored item is During my studies my understanding of the most important concepts in the domain has increased $(\mathrm{M}=3.48)$, which shows the importance they give to reflection on research product, rather than research process.

In contrast, among the lowest scored items we find During my studies there were opportunities to talk with researchers about scientific research $(\mathrm{M}=2.09)$; During my studies I had opportunities to socially interact with researchers within the university $(\mathrm{M}=2.10)$; During my studies I became involved in my teachers' research $(\mathrm{M}=2.21)$ and During my studies I made a contribution to development in my field $(\mathrm{M}=2.31)$.

As we can see, the lowest items scored by students relate to the integration into the research community during their degree and to the contact they experienced with the teachers' research.

Considerable differences were found when comparing means between the level of students. We applied t-test for independent samples to compare the means among independent groups to determine whether there were statistical meaningful differences. In order to achieve meaningful results when performing comparisons of groups, we grouped the students by junior-senior students: Group 1 (junior) are students in the two first year of the degree and Group 2 (senior) are students in the two lasts years of the degree. The results reveal the following statistically significant differences with respect to the level of study (Table 5). 
Table 5

Comparison of mean scores between groups

\begin{tabular}{lccc}
\hline ITEM & $\begin{array}{c}\text { Group 1 } \\
\text { Students in } \text { 1 }^{\text {st }} \\
\text { and 2 }{ }^{\text {nd }} \text { year }\end{array}$ & $\begin{array}{c}\text { Group 2 } \\
\text { Students in 3 } \\
\text { and }^{\text {th }} \text { year }\end{array}$ & $\begin{array}{c}\text { Sig. } \\
\text { (bilateral) } \\
\mathrm{P}<.05\end{array}$ \\
\hline $\begin{array}{l}\text { 7. During my studies, I was inspired to learn more } \\
\text { about this discipline }\end{array}$ & 3.40 & 2.69 & .00 \\
$\begin{array}{l}\text { 10. During my studies, I felt part of the university's } \\
\text { academic community }\end{array}$ & 3.13 & 2.61 & .01 \\
$\begin{array}{l}\text { 12. During my studies my teachers encouraged } \\
\text { me not to be satisfied with an explanation too } \\
\text { quickly }\end{array}$ & 3.15 & 2.71 & .03 \\
$\begin{array}{l}\text { 21. During my studies, I felt involved in the univer- } \\
\text { sity's research culture }\end{array}$ & 2.50 & 2.10 & .03 \\
$\begin{array}{l}\text { 24. During my studies, my interest in research in } \\
\text { this area was increased }\end{array}$ & 3.29 & 2.82 & .01 \\
$\begin{array}{l}\text { 27. During my studies, the teachers encouraged us } \\
\text { to ask critical questions about our work }\end{array}$ & 3.92 & 3.47 & .03 \\
$\begin{array}{l}\text { 39. Education in which scientific research is central } \\
\text { stimulates my learning }\end{array}$ & 3.37 & 2.94 & .03 \\
\hline
\end{tabular}

Students in the first two years gave higher scores than the students in the two last years of the degree, especially significant in those items related to, first, academic disposition (items 12 and 27) or students developing approaches and dispositions towards knowledge development and research, defined as intangible aspects by Neumann (1992). This was followed by the integration of research (items 10 and 21) and beliefs towards research (item 39). Moreover, finally, related to motivation for research were items 7 and 24. This fact should be taken into consideration and work towards finding the reasons motivation decreases in students who are in the last two years of their bachelor's degree, as those are the years in which they develop their final research project, and the subjects have a higher research component.

Regarding the students' perception of research integration, we can affirm that students agree that education in which scientific research is central stimulates their learning and that research culture stimulates their learning process. Therefore, research improves their academic disposition. They also feel they did not contribute to development in the field, so they should be more involved in real empirical research in the primary teaching professional context.

They affirm there are not enough opportunities to be integrated within the research community because they did not have the opportunity to talk with researchers, being involved in teacher's research or being aware of research done on the topics related with the curriculum subjects. 
We strongly believe this is significant data that we should not neglect when transforming and improving the education of future teachers.

\section{Discussion}

To understand the way students perceive research integration in their courses is essential in order to improve the curriculum in teacher education, especially when the goal of universities is to strengthen the links between teaching, learning, and research.

To apply this study in our faculty has been very useful to provide information to teachers and degree coordinators by increasing their understanding of student's perceptions. In UAB, most professors develop research themselves. This close link between teaching and research is considered by Elen and Verburgh (2008) to be at the heart of academic institutions. However, when examining the results from SPRIQ, the link appears to be not sufficient for professors to engage students in research or even to transfer knowledge and skills in the university class. There is a lack of research process and research result components in the different courses of the degree.

From the findings of our research, we conclude that teacher education programmes should reshape the development of research skills based on contemporary approaches. Universities need to reshape the teacher education programmes, because the traditional approach to educational research is not of much use to teachers. Teacher education programmes should be focused on effective implementation of research-based approach to ensure closer relation between classroom realities and pedagogical theories and practices, in order to prepare student teachers to integrate research in their future career.

Based on our research data, we underline the need to improve the development of research skills from the first years of initial teacher education, focusing on a range of skills necessary for doing research, including informationseeking skills, methodological and data analytical skills, communicating skills.

Students' research final projects need to be related to on-going research at the university and/or development projects in school. In this way, universities promote and push forward research priorities, and students will be able to be involved in the real research life of the institution to which they belong.

The most suitable form of research for student teachers at the bachelor's level is recommended the action research type of work as it will prepare prospective teachers to examine their professional practice and continually improve teaching and learning in their classrooms and beyond.

Findings from students' responses show that they are more consumers 
than producers. We emphasise the importance of student teachers being able to both consume as well as produce research in order to develop professionally.

\section{Conclusions}

This paper supports the idea that it is imperative for the future teachers to have the capacity to integrate research into their professional practice because of a number of reasons, including the sensitive nature of their context, the rapidly evolving nature of teaching, needing to test new pedagogical approaches and understand their impact on learning, needing to determine the effectiveness of their teaching strategies and make judgments, needing to find and analyse problems they may face in their future work, and needing to study and develop their own professional practice on a continuous bases. We uphold the idea that it is no longer sufficient for teachers to be limited to classroom research; connecting teacher research, school development, and system reform is recommended.

We find the development of the national curriculum guidelines on teacher education that will provide the policy for the institutions' programme descriptions to be useful. They will ensure a nationally coordinated teacher education that satisfies the quality requirements of the teacher education programmes for pre-school, primary and secondary education.

In the framework of research-based approach implementation, we suggest taking into consideration two best practices:

1. The Finish model of research-based teacher education. ITE in Finland is research-based, and the objective is to educate teachers to have the capacity to utilise the most recent research in the fields of education and the subjects taught. This model has four characteristics: 1) the study programme is structured according to a systematic analysis of education; 2) all teaching is based on research; 3 ) activities are organised in such a way that students can practice argumentation, decision making and justification when inquiring about and solving pedagogical problems; and 4) the students learn formal research skills during their studies (Toom et al., 2008).

2. The Norwegian experience that has already drawn international attention. Report of European Commission (2013) states: In Norway, the Ministry of Education and Research has started a research programme for teacher educators (PRAKUT), engaging them in practice based educational research in close cooperation with schools. This programme is supported by a national graduate school in teacher education (NAFOL), 
where teacher educators can join $\mathrm{PhD}$ programmes. While supporting the development of teacher educators' research expertise, this initiative also contributes to the development of the knowledge base on teaching, teacher education and teachers.

Achieving the target of developing student teachers as researchers will remain a goal for universities.

\section{References}

Beretter, C. (2002). Education and the mind in the knowledge age. Mahwah, NJ: Laurence Erlbaum. Buckley, C. A. (2011). Student and staff perceptions of the research-teaching nexus. Innovations in Education and Teaching International, 48, 313-322.

Carroll, J. M. (1998). Minimalism beyond the Nurnberg Funnel. Cambridge, MA: MIT Press. Communication from the Commission to the Council and the European Parliament. (2007, August 3). Improving the quality of teacher education. Retrieved from http://europa.eu/legislation_ summaries/education_training_youth/lifelong_learning/c11101_en.htm

Elen, J., \& Verburgh, A. (2008). Bologna in European research universities. Implications for bachelor and master programs. Antwerpen: Garant.

European Commission. (2013). Supporting teacher educators for better learning. Outcomes. Brussels: European Commission.

European Trade Union Committee for Education [ETUCE]. (2009). Teacher education in Europe: An ETUCE policy paper. Brussels: ETUCE. Retrieved from www.csee-etuce.org/images/attachments/ ETUCE_PolicyPaper_en.pdf

European Union. (2007). Information and notices: Notices from European Union institutions and bodies (No. 2007/C 300/09). Official Journal of the European Union, 50. Brussels: European Union. Retrieved from https://eur-lex.europa.eu/legal-content/EN/TXT/?uri=uriserv:OJ .C_.2007.300.01.0006.01.ENG\&toc=OJ:C:2007:300:TOC

European Commission. (2015). Shaping career-long perspectives on teaching. A guide on policies to improve initial teacher education. Retrieved from http://omk-obrazovanje.gov.rs/wp-content/ uploads/2016/o3/initial-teacher-education_en.pdf

Healey, M. (2005). Linking research and teaching exploring disciplinary spaces and the role of inquiry-based learning. In R. Barnett (Ed.), Reshaping the university: New relationships between research, scholarship and teaching (pp. 30-42). Maidenhead, UK: McGraw-Hill/Open University Press.

Hopkins, D. (2008). A teacher's guide to classroom research (4th ed.). Maidenhead, UK: Open University Press/McGraw-Hill Education.

Jenkins, A., Blackman, T., Lindsay, R., \& Paton-Saltzberg, R. (1998). Teaching and research: Student perspectives and policy implications. Studies in Higher Education, 23, 127-141. 
Jenkins, A., \& Healey, M. (2009). Developing undergraduate research and inquiry Retrieved from http://www.heacademy.ac.uk/ourwork/supportingresearch/teachingandresearch Kansanen, P. (2007). Research-based teacher education. In R. Jakku-Sihvonen \& H. Niemi (Eds.), Education as a societal contributor (pp.131-146). Frankfurt-am-Main: Peter Lang.

Kincheloe, J. (2012). Teachers as researchers. Qualitative inquiry as a path to empowerment. London, UK: Routledge.

Kraft, N. (2001). Certification of teachers: A critical analysis of standards in teacher education programs. In J. Kincheloe \& D. Weil (Eds.), Standards and schooling in the United States: an Encyclopaedia (pp. 48-58). Santa Barbara, CA: ABC.

Krokfors, L. (2007). Two-fold role of pedagogical practice in research-based teacher education. In R. Jakku-Sihvonen \& H. Niemi (Eds.), Education as a societal contributor. Reflections by Finnish educationalists (pp.147-159). Frankfurt-am-Main: Peter Lang.

Krokfors, L., Kynslahti, H., Stenberg, K., Toom, A., Maaranen, K., Jyrhm, R., et al. (2011). Investigating Finnish teacher educators' views on research-based teacher education. Teaching Education, 22(1), 1-13.

Neumann, R. (1992). Perceptions of the teaching-research nexus: A framework for analysis. Higher Education, 23, 159-171.

Niemi, H., \& Jakku-Sihvonen, R. (2006). Research-based teacher education. In R. Jakku- Sihvonen \& H. Niemi (Eds.), Research-based teacher education in Finland - Reflections by Finnish teacher educators (pp. 31-50). Turku: Finnish Educational Research Association.

Robertson, J., \& Blackler, G. (2006). Students' experiences in learning in a research environment. Higher Education Research and Development, 25, 215-229.

Taber, K. (2007). Classroom-based research and evidence-based practice. A guide for teachers. London, UK: Sage Publications.

Toom, A., Kynäslahti, H., Krokfors, L., Jyrhämä, R., Byman, R., Stenberg, K., et al. (2010). Experiences of a research-based approach to teacher education: Suggestions for future policies. European Journal of Education, 45(2), 331-344.

Toom, A., Krokfors, L., Kynäslahti, Stenberg, K, Maaranen, K., Jyrhämä, R., et al. (2008). Exploring the essential characteristics of research-based teacher education from the viewpoint of teacher education. Retrieved from www.pef.uni-lj.si/tepe2008/papers/Toom_etal.pdf Visser-Wijnveen, G., van der Rijst, R., \& van Driel, J. (2015). A questionnaire to capture students perceptions of research integration in their courses. Higher Education, 71, 473-488.

Westbury, I., Hansen, S.E, Kansanen, P., \& Björkvist, O. (2005). Teacher education for research-based practice in expanded roles: Finland's experience. Scandinavian Journal of Educational Research, 49(5), $475-485$.

Wilkinson, R., \& Walsh, M. (2015). Integrating Content and Language in Higher Education. Frankfurt: Peter Lang. 


\section{Biographical note}

INGRID AgUD, PhD, is lecturer in the field of Theory and History of Education at the Faculty of Education Sciences, Universitat Autònoma de Barcelona. She is member of the Research Group CER-Migracions EMIGRA focused on the study of migrations, education and gender. Her research focuses on children and youth and is characterized by an intersectional approach. She also undertakes research to improve the quality of teaching and evaluation in higher education.

Gerogeta Ion, PhD, is lecturer at the Department of Applied Pedagogy of the Universitat Autònoma de Barcelona. Her research topics are related to the study of the higher education organization and management and gender studies. At the same time she is conducting research about competences-based assessment in higher education. She collaborates with Spanish and international research groups in topics related to the research-based education. 